for Gaia) doesn't like or dislike anything. So why does Lovelock persevere with this language and mode of thinking? Why doesn't he let his analysis of energy systems and feedbacks in climate and the carbon cycle stand on its own? Lovelock is aware, with regard to his personalization, of the criticisms of scientists. Yet he claims to be unrepentant.

Certainly the language of goals and intentions gives emotional juice to the arguments. But when Lovelock promotes a metaphor that mixes in false science, the metaphor itself is tainted and must be dismissed.

He makes a case that metaphor is needed. But to pronounce that Gaia is "angry" with us, or that she will "eliminate those that break her rules" weakens the otherwise rational (albeit controversial) scrutiny of our complicated global jam. Too often, Gaia here seems less like science and more like one man's mythology elevated into the service of deeply felt environmental concerns. Lovelock likens the incomprehensibility of Gaia to that of God, valorizes those who declare allegiance to Gaia, and claims that Gaia theory is a seed from which an "instinctive environmentalism can grow; one that would instantly reveal planetary health or disease and help sustain a healthy world". What does "instantly reveal" mean?

Read this book for its thoughtful sections on global energy and climate, but steer clear of its web of Old Testament-like prophecy. Tyler Volk is in the Department of Biology, New York University, New York 10003, USA.

\title{
Climbing Mount Schiehallion
}

\section{Weighing the World: The Quest to Measure the Earth \\ by Edwin Danson \\ Oxford University Press: 2006. 289 pp. \\ $\notin 17.99, \$ 29.95$}

\section{Patricia Fara}

The Enlightenment recluse Henry Cavendish is remembered for being eccentric, synthesizing water and determining the Earth's density. Notoriously taciturn, Cavendish apparently made one joke in his entire life: commiserating with the ill-health of his colleague John Michell, he hoped that "it may at least permit the easier and less laborious employment of weighing the world". Their efforts with a torsion balance eventually proved successful, but these heroes of mensuration make surprisingly brief appearances in Weighing the World. Instead of describing their laboratory experiธ ments, Edwin Danson focuses on a far less famous line of investigation - measuring the attraction of mountains.

Danson, a civil engineer, has coined a misleading title for his book, which turns out to be mainly a history of surveying in Britain and India during the long eighteenth century.' He starts his account in seventeenth-century France, when perplexing results from accurate instruments forced cartographers to challenge the long-standing assumption that God had made the Earth a perfect sphere. They concluded that the Earth must be slightly squashed - but, as Voltaire put it, battles raged about whether it resembled a melon or a lemon. Several expeditions later, it seemed that the Earth was more like a pear. Surveyors faced an additional challenge to accuracy. Isaac Newton himself pointed out that, according to his gravitational theory, mountains must be centres of attraction. But Newton was wrong to doubt that instruments would ever be sensitive enough to detect this influence - large mountains can affect readings strongly enough to yield mapping errors of more than a mile.

Danson's book revolves around an expedition to Mount Schiehallion in the Scottish Highlands, which he interprets as a key founding event in the science of geodesy. Organized by the Royal Society, an underpaid team set out with the finest available equipment, but tempers flared during long weeks of arduous labour. Sleeping in cramped tents and hampered by atrocious weather, astronomers and surveyors quarrelled about their duties, and personality clashes were further exacerbated by class differences - although the astronomer royal, Nevil Maskelyne, redeemed himself by sending a Stradivarius to the ghillie whose fiddle had been burnt during the farewell celebrations. Back in London, Maskelyne calculated Schiehallion's attraction by comparing the astronomical and land measurements of its width. Armed with this result, and thanks to the surveyors' astonishing feat of triangulating the whole mountain to find its volume, he estimated its density.

This is a handsome book, brimming with original images as well as modern diagrams, although someone at the publisher apparently believes that the secondary in "secondary sources" means less important. An alert editor might have prevented Danson from dating experiments to test Newton's gravity to 15 years before he published the Principia, and also toned down phrases such as "Mother Nature was not about to let her foolish children exploit her oblate body." But this modern surveyor's love for both his craft and his historical material emerges strongly. Danson not only explains technicalities clearly, but also gives readers some notion of the endurance and attention to detail involved in drawing maps before satellite systems removed the hard work - and the romance - from surveying.

Danson is a narrative rather than an analytic author, who intersperses scientific discussions with ample background information of varying relevance. His generosity in reproducing the minutiae of his research unfortunately obscures the plot-line leading to today's theories of Earth's structure, and this emphasis on presenting facts precludes a discussion of their significance, which would have given his work a wider appeal. Although the dust-jacket blurb highlights the novelty of Danson's narrative, his text skates around the interesting question of why Maskelyne's strenuous activity on Schiehallion has been forgotten, whereas Michell and Cavendish have acquired canonic status. To say they got a better answer is too simple: Danson's work implicitly illustrates how the theoretical work of scientists was and still is - more esteemed than the practical contributions of engineers.

Patricia Fara is at Clare College, Cambridge. Her recent books include Newton: The Making of Genius (2002) and Fatal Attraction:Magnetic Mysteries of the Enlightenment (2005). 